\title{
VASTU IN CONSTRUCTION IN CIVIL ENGINEERING POINT OF VIEW
}

\author{
Ranjeet. $P^{1}$, D.V.S. Narshima Rao ${ }^{2}$, Md. Akram Ullah Khan ${ }^{3}$ \\ ${ }^{1}$ Assistant Professor, Civil Department, GNITC, Telangana, India. \\ ${ }^{2}$ Associate Professor, Civil Department, GNITC, Telangana, India. \\ ${ }^{3}$ Assistant Professor, Civil Department, GNITC Telangana, India.
}

\begin{abstract}
Vastu the Indian ancient science which is used for civil engineer in many types of constructions like, residential houses, corporate buildings, Temples etc., Vastu is the science which helps the civil engineer to find exactly where and which room should be and it is truly in coordination with the nurture. It is mainly depends up on the sun light and air flow. Reference points for vastu starts form the north point. In this paper, we discuss about the directions and air flow and vastu, which is related to civil engineer.
\end{abstract}

Keywords: Indian Vastu, Directions, Positive Energy, Five Elements of Environment etc...

\section{INTRODUCTION}

Vastu it is ancient science where it is used in many types of constructions like residential houses, corporate buildings, temples etc., basically it is depends upon the sun light and air flow. It is also called as science of architecture.

It has its own importance in civil constructions where an engineer should know about it.

Vastu the word is an ancient method where the ancient engineer vishwakarma used it in all types of constructions like forts, temples and old historical monuments.

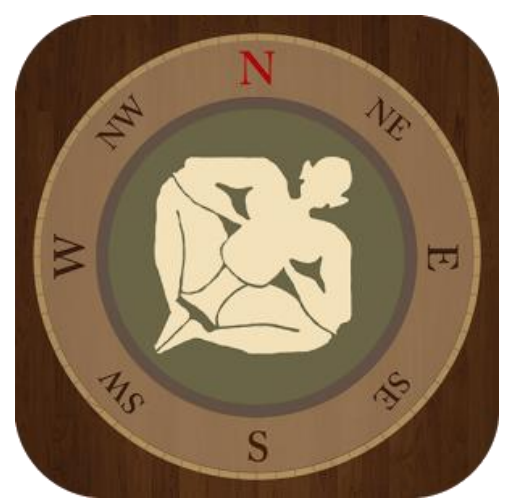

Fig: 1 Vastu and directions

It is interplay of various forces which are involved in solar system like land, wind, water, fire and sky.

It is an ancient construction science which is covers the theory of architectural works and also the philosophy.

It is based upon various energies with are present in this atmosphere like sun energy, earth energy, magnetic energy, wind energy, light energy, thermal energy and cosmic energy.
Utilizing of these types of energies in the construction it give the best positive result.

Vastu can be considered for single room in the entire building. The correct combination of vastu rooms gives the positive result to the entire house or building.

Not only for buildings, vastu can be considered for every city planning, house, temple, industries, towns etc.

Vastu is the only this which depends up the sun light and air flow of the environment system. To start consideration of vastu we need to find the North direction for the reference point because north is considered as auspicious since of magnetic line of forced moves for north to south.

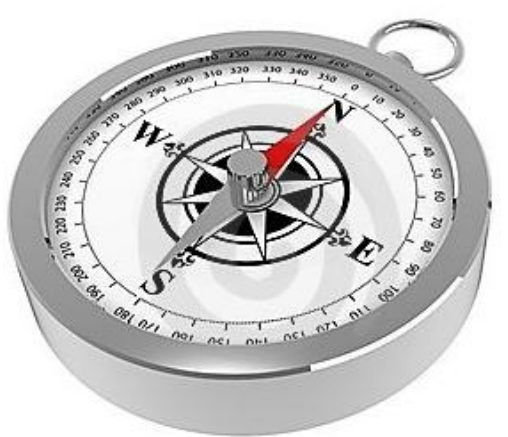

Fig: 2 Compass for directions

\section{RELATION WITH VASTU TO CIVIL ENGINEERING}

Vastu is a part of civil engineering as the ancient engineer Vishwakarma words it is said that the vastu is used in every part of civil structure, and it has no expire date.

Now a day's civil engineer are particular about the construction as per vastu. 
In civil engineering point of view vastu helps the engineer to show the proper direction of doors, windows, bed directions, bedroom design, interior and entrance.

All living beings in this universe is moulded by nature with 5 elements like earth, water, fire air and sky and these elements should be balanced for a harmonium to live in. It is a science of architectural in construction balancing all these five elements for good health and prospects of wealth of any living being.

It also helps to give information about the house or building facing. The change in direction gives the change in vastu for the building or house.

\section{VASTU TIPS}

The vastu tips may varies from the facing of house directions. There are four direction of house or building facings. They are

- East facing house/ Building

- West facing house/ Building

- North facing house/ Building

- South facing house/ Building

\subsection{Vastu Tips For East Facing House/ Building}

East facing indicates the growth of life which is given by the sun light. In this the main entrance must be at north-east corner where the sun energy/light moves directly into the house. Where there are more ambiances in house by sun light there will be more growth or life in health and wealth.

\subsubsection{Location of Rooms As Per Vastu In East}

\section{Facing House/ Building}

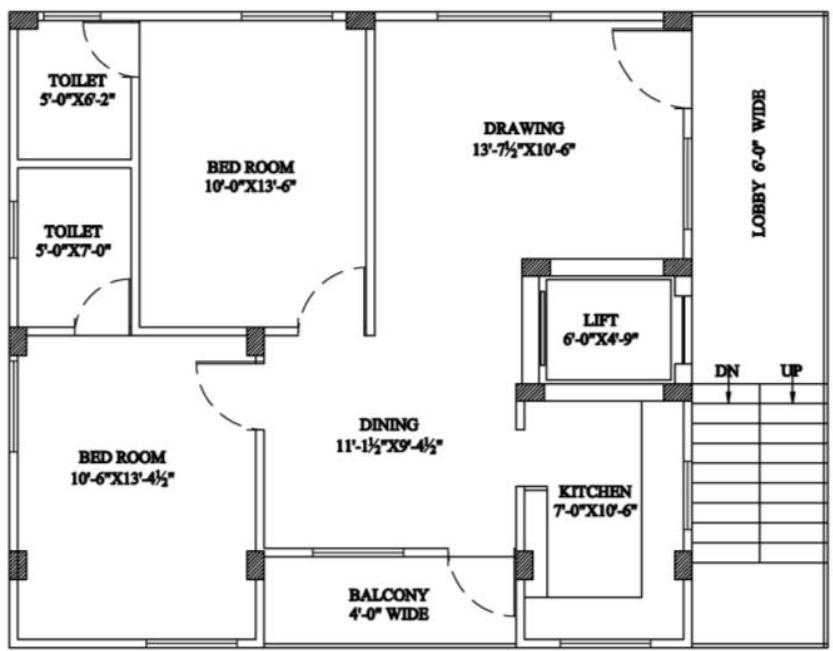

Fig: 3. East Facing House Plan

- Entrance, Hall, Puja Room should be at north-east corner or east.

- Dining, balcony should be at south side

- Kitchen, stair case and bath room should be at south-east corner.

- Master bed room should be at south-west corner.
- Children bed room, bath room and stair case should be at north-west corner

- Second entrance for east facing house/building should be in the north side towards east corner.

- Balcony may be at north-west corner.

- The flooring height should be more at south-west corner when compared to other sides or directions.

- There should be more loads like cupboards or lockers in south-west.

- Cupboards or shelves for all the rooms should be for west side or south side walls.

- The door for children bed room should be at south side towards the south-east corner.

- The door for master bed room should be at east side towards north east corner.

- Bath room doors should be towards south or north-east corner.

- The bed in bed room should touch the south side wall and the facing for sleeping must to head at south side and legs towards north side.

- The main gate entrance should be at north-east corner.

- The height of compound wall should be more height at south-west corner when compared to other sides.

- We need to turn to words right side when we are moving up on to the stairs.

- Comparing to all the rooms the master bed room should be bigger.

- Over head tank should be placed at south-west corner because the corner should take more loads to balance the vastu.

- The underground tank should be place at north-east corner.

\subsubsection{Location of Rooms As Per Vastu In West}

\section{Facing House/ Building}

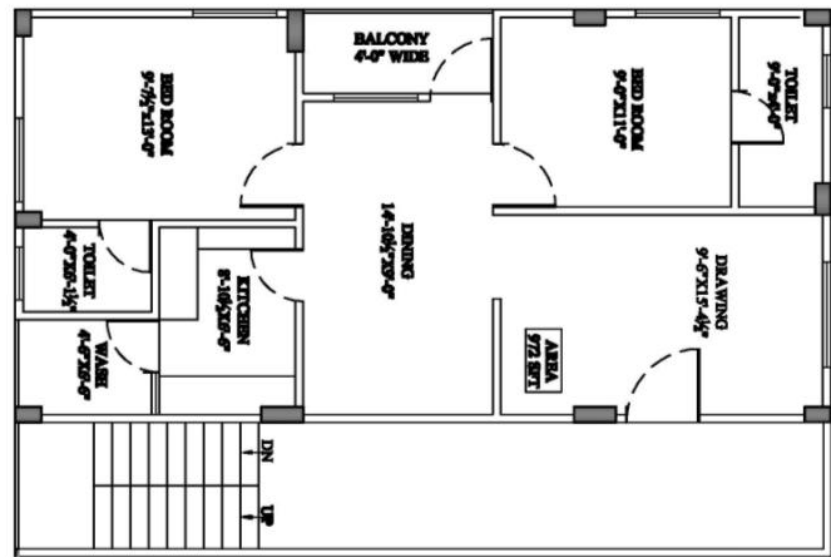

Fig: 4. West Facing House Plan

- The points which are mentioned in East facing Plan will be applicable for West and North facing houses.

- In the north facing house the main entrance should be place at north-east corner or at the center of north wall. 


\subsubsection{Location of Entrance Door As Per Vastu In}

\section{South Facing House/ Building}

The main entrance or the main gates place a main role in a building/house. As it is said by vishwakarma the god of Indian architectural, in the south facing house the main door should not be place in the center of the south wall because the center position of south wall is called as yama dhawar, and the main entrance should not be placed at the south-west corner because the negative energy travels from south-west corner. The correct place to place the main door is southeast corner because the positive energy travels from southeast corner.

- Positive energy means good health, wealth and good relationship in family and business.

- Negative energy means the disturbances in family, health and wealth.

- Placing main door in center of south wall results in the death of head in the family or in the house/building.

\section{PLACE AND DIRECTION INDICATIONS}

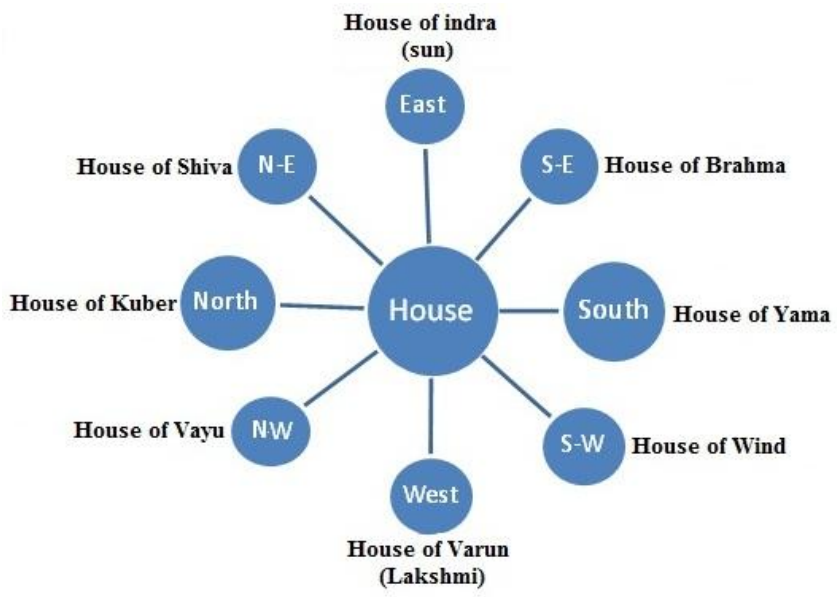

Fig: 5 Indication of directions in residential house

The directions of places and their significance help the builder or engineer to know the tips for vastu.

East - it is called house of indra. Main entrance at this place gives positive energy like health, and good wealth.

South- East - it is also called house of bramha. Kitchen or bath room should be constructed at this place. No main door should be placed.

South - It is also called as house of Yama. The god of death is call Yama. Main Entrance at the center of south wall result the death of main person in that family. Avoid main door in center of south wall.

South-West - It is also called as House of Wind. Main bedroom should be constructed at this place for peace full sleep. It is a place where positive energy enters.

West- It is also called as House of Varuna or Lakshmi. Main Entrance at center of west wall gives good wealth.
North -West: It is also called as House of Vayu. This is the place where we keep heavy load like lockers for money and gold. This help to save the money for more time.

North: it is also called as house of kuber the god of money is called kuber. No toilets and no water drains should be kept at this place.

North-East: it is also called as house of Shiva. To should be free from all the constructions and it should to open to sky. The more increase of this side give the more increase of health, wealth, and good family relations.

\section{DIMENSIONS AND PLACING OF DOORS} AND WINDOWS AS PER VASTU

- The standard size of main door should be 4 x 7 feet. This allows the furniture safely inside the house.

- The standard size of windows should be $4 \times 4$ feet. This helps for good ventilation.

- The standard size of ventilators in bath room should be $1.5 \times 1$ feet.

- The standard size of ventilator in kitchen should have a diameter of 1 feet (if circle) $1 \times 1$ feet (if it is square).

- Door and window should be exactly opposite for free flow of air and light.

- No two windows or no two doors should not fall at the center of opposite window or door.

- No low roofs should be constructed.

- Maintain even number of doors and even number of windows.

- Maintain at least 2 main doors one at east and one at north or one at west and one at north. As per facing of house.

- Room or house should not have only 4 corners.

\section{THINGS THAT SHOULD NOT BE KEPT /} SHOULD NOT TO BE DONE IN HOUSE AS PER

\section{VASTU}

- Never keep medicines in kitchen because kitchen is place where health environment takes place but when we keep medicines in kitchen it provide negative energy which effects the healthy environment.

- Never keep a mirror in front of bed in bed room because the person when sleep goes into subconscious states where sole moves out and comes in when we wake up. When the sole comes out of body when we reach subconscious state the sole should not see the mirror if the sole see the mirror as soon as it comes out from the body it results death.

- Plants should not be kept in bed room because it produces carbon dioxide. This is not good for health.

- No devil paintings or un natural arts should not be in house.

- Broken mirror, Painting of maha bharata, painting of horse which has one or two legs in air, sinking boat. 
- Idol of nataraja, waterfalls and terrifying giants and demons, War scenes, negativity in images etc.,

- Don't construct beam in the center of room and don't construct pillars inside the room

- Avoids pet cats in home or office because they stay in negative energy places.

- Avoid T.V. set in bed room.

- Do not use separate mattresses and bed sheets on a king size bed in bed room

- No mirrors should be placed in kitchen.

- No TV and Computer should be kept actually opposite to the bed. After switching off the tv or computer monitor the screen shows the reflection of bed it is a bad indication.

\section{THINGS THAT SHOULD BE IN HOUSE/ DO}

\section{IN HOUSE AS PER VASTU}

- After bed is layed in bed room the room should have less space at south and west sides when compare to east and north.

- Mirror should be placed at south corner wall and it should not be in front of bed.
- Keep a window or a door at north-east corner. And keep the window always open at that corner.

- Keep Buddha or load Ganesha statue in front of main door.

- All idols of god should face east for good result.

- Room or house should always be in square or rectangles. And wall should be in $90^{\circ}$.

- Air flow and sun light should always come from north east direction.

- Adopt pet dogs, because dogs stay in positive energy places.

- Cook facing east.

- Keep water bodies like pot or bowl of water with flowers. At north-east corner or at the main entrance.

- Take all the decision facing towards north for good result.

- Study facing towards east and north for better and good result.

- Construct a window or door for a puja room in such a way that the morning sun rays directly fall on the idols in puja room, which give more energy or power to your prayers.

- South-west corner wall should be higher than compare to other direction of walls.

\section{SCIENTIFIC REASONS FOR THE VASTU.}

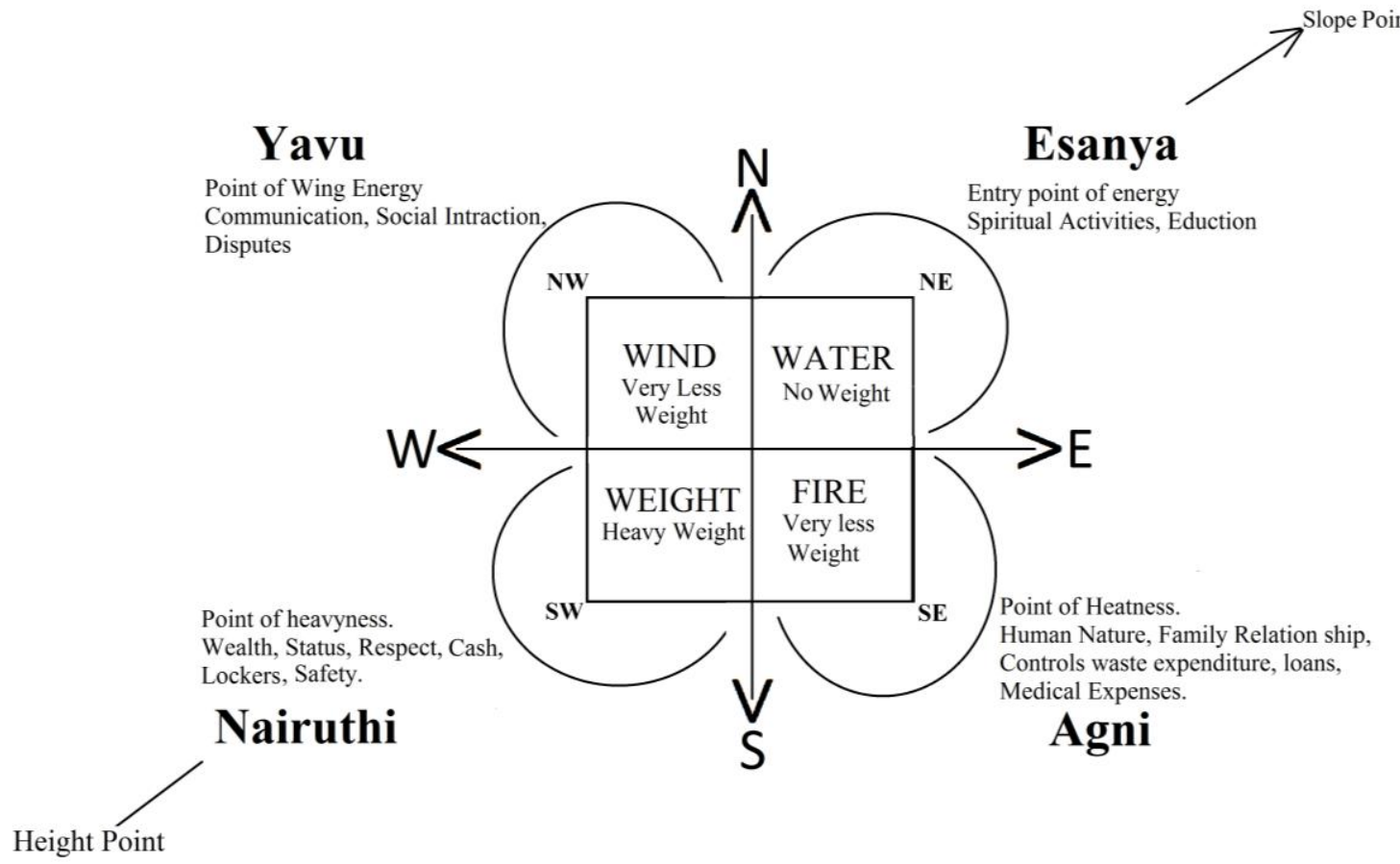

Fig: 6 Specifications and direction of vast for a construction.

- Vastu is a science of building construction, balancing all the five elements like water, air, five, space, and land of the nature for a healthy living and prosperous life.

- The Foreign invasion lead to lose the grip on vastu with technological advances like mechanical ventilations and artificial lightings with extra comforts in life unfortunately neglecting laws of nature in bringing ill health to us.

- Vastu is an observatory science in nature and applied science in our life.
- The invisible energies which were discovered recently like electromagnetic fields, ultrasonic and infrared rays, gravity and radiations will directly have impact on the space we live and vastu shastra balances all these energies for healthy and prosperous happy life to live in.

- The fundamental principal of vastu mainly focuses on law of weights (i.e., low weight area and heavy weight area) and balance of weights in accordance with nature. 


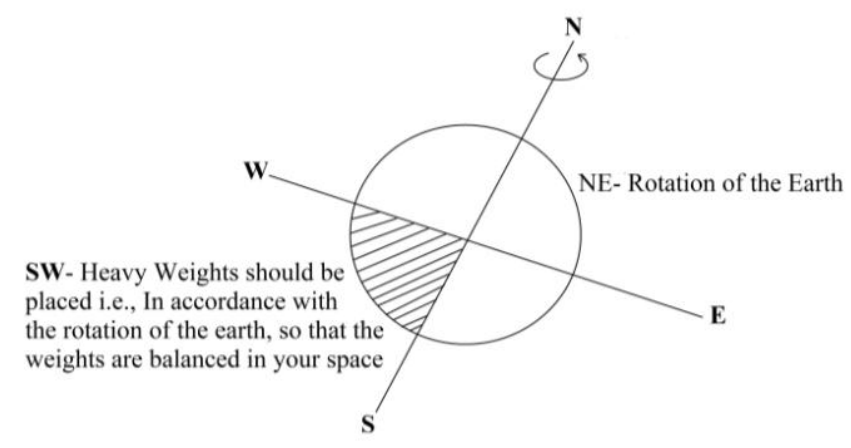

Fig: 7 Direction of balancing weights of vastu for home/building

- All energies arise from east and sun is only source of renewable abundant energy to be utilized for our future which brings life, vitamins(vitamin D), UV radiation and nutrients, and if east side is blocked completely, artificial lighting and mechanical ventilation like electric chimneys etc., has to be adopted which will lead to more electrical consumption and wastage.

- Natural lighting in kitchen should have more than 6001000 LUX, ( light is measured in LUX) according to BIS standards which is equivalent to 100 watts bulb of artificial lighting and also exposure of UV rays in the morning time of cooking enriches our food with natural vitamins and nutrients from direct sun light.

- A building is compared to human body and it living organism in accordance with five elements of nature.

- Table: 1 Direction of balancing weights of Vastu for home/building

\begin{tabular}{|c|c|c|}
\hline Region & Human Body & Building \\
\hline Top & Head & Roof \\
\hline Middle & $\begin{array}{c}\text { Hands and middle } \\
\text { portion }\end{array}$ & $\begin{array}{c}\text { Basement and } \\
\text { foundation } \\
\text { (Transmitting the } \\
\text { dead and live load) }\end{array}$ \\
\hline
\end{tabular}

- The amount of gap left in the middle portion of house is called Bhrama sthana which is like a lungs space to a house bringing good health and prosperity, even Romans also followed this principal in construction.

- Vastu encourages the green building construction by use of natural materials with coordination of natural lightning and ventilation decreasing the power consumption and utilizing sun's energy and nature up to maximum extent.

- Vastu at mohanjdaro in ancient city in the year $5500 \mathrm{AD}$ in Indus valley built all the houses in rectangular shape and cooking area located at south-east with an open central court yard, great architecture monuments like Egyptian pyramids, roman coliseum, Greek parathion and Taj mahal where built according to vastu.

- One has to face withdrawal symptoms after vastu rectification for a good cause and better guaranteed future

\section{CONCULSION}

- In this vastu concludes that vastu compares the building with a human body.

- The five elements which are co related to this environment is said to be vastu and the balancing part of all type of construction can only be done by vastu.

- In this vastu concluded that it is a natural science which can be seen everywhere in really life.

- The vast is applicable for all the aspects and the aspects are mentioned in the above theory.

\section{REFERENCES}

[1] B.B. Dutt (1925), Town Planning in Ancient India at Google Books

[2] V. Chakra borty, Indian Architectural Theory: Contemporary Uses of Vastu Vidya at Google Books

[3] Important Concepts of Vasthu Shasthra Traditional Indian Architecture

[4] Vastu: Transcendental Home Design in Harmony with Nature, Sherri Silverman

[5] Prabhu, Bala gopal,T.S and Achyuthan,A, "A text Book of Vastuvidya", Vastuvidyapratisthanam, Kozhikode, New Edition, 2011.

[6] Prabhu, Bala gopal,T.S and Achyuthan,A, "Design in Vastuvidya", Vastuvidyapratisthanam, Kozhikode.

[7] Prabhu, Bala gopal,T.S and Achyuthan,A, "Manusyalaya candrika- An Engineering Commentary", Vastuvidyapratisthanam, Kozhikode, New Edition, 2011.

[8] Vastu-Silpa Kosha, Encyclopedia of Hindu Temple architecture and Vastu/S.K.Ramachandara Rao, Delhi, Devine Books, (Lala Murari Lal Chharia Oriental series)

[9] D. N. Shukla, Vastu-Sastra: Hindu Science of Architecture, Munshiram Manoharial Publishers, 1993.

[10] B. B. Puri, Applied vastu shastra vaibhavam in modern architecture, Vastu Gyan Publication, 1997.

[11] Vibhuti Chakra barti, Indian Architectural Theory: Contemporary Uses of Vastu Vidya Routledge, 1998.

\section{BIOGRAPHIES}

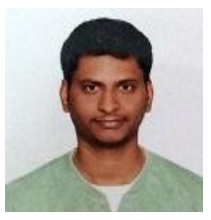

Ranjeet.P holds $M$ Tech Degree in Transportation Engineering from JNTUH, Telangana, India. Presently working as Assistant Professor in Civil Department in GNITC, Telangana, India.

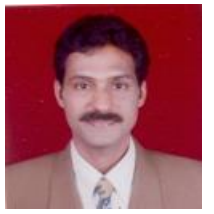

DVS Narsimha Rao, MSc (Geology), M.Phil working in Civil Department as an Associate professor in Guru Nanak Institutions Technical Campus

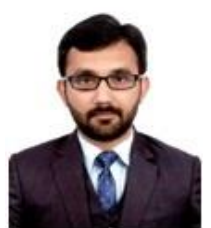

Mohd Akram Ullah Khan, Research scholar in the department of Applied Geology in Osmania University and working in Civil Department as an Assistant professor in Guru Nanak Institutions Technical Campus 